Article

\title{
Prevalence of Bovine Norovirus and Nebovirus and Risk Factors of Infection in Swedish Dairy Herds
}

\author{
Madeleine Tråvén ${ }^{1, *(\mathbb{D})}$, Charlotte Axén ${ }^{2}$, Anna Svensson ${ }^{1}$ (D) , Camilla Björkman ${ }^{1}$ and Ulf Emanuelson ${ }^{1}{ }^{(\mathbb{C}}$ \\ 1 Department of Clinical Sciences, Swedish University of Agricultural Sciences, P.O. Box 7054, \\ SE-75007 Uppsala, Sweden; anna.svensson@slu.se (A.S.); camilla.bjorkman@slu.se (C.B.); \\ ulf.emanuelson@slu.se (U.E.) \\ 2 Swedish National Veterinary Institute, SE-75189 Uppsala, Sweden; charlotte.axen@sva.se \\ * Correspondence: madeleine.traven@slu.se
}

Citation: Tråvén, M.; Axén, C.;

Svensson, A.; Björkman, C.;

Emanuelson, U. Prevalence of Bovine Norovirus and Nebovirus and Risk

Factors of Infection in Swedish Dairy

Herds. Dairy 2022, 3, 137-147.

https://doi.org/10.3390/

dairy3010011

Academic Editor: Ana Marcia de Sá Guimarães

Received: 16 September 2021

Accepted: 28 December 2021

Published: 11 February 2022

Publisher's Note: MDPI stays neutral with regard to jurisdictional claims in published maps and institutional affiliations.

Copyright: (c) 2022 by the authors. Licensee MDPI, Basel, Switzerland. This article is an open access article distributed under the terms and conditions of the Creative Commons Attribution (CC BY) license (https:// creativecommons.org/licenses/by/ $4.0 /)$.

\begin{abstract}
Enteritis is the major cause of mortality in neonatal calves. Diagnostic work to detect the pathogens involved and identification of risk factors for such infections are imperative to improve calf health. Bovine norovirus (BNoV) and nebovirus prevalence was investigated using RT-PCR in 50 dairy herds in five geographic regions of Sweden. BNoV and nebovirus were found to be common infections in young dairy calves. BNoV was detected in $20 \%$ of 250 calves in $48 \%$ of the herds. Nebovirus was detected in $5 \%$ of the calves in $16 \%$ of the herds. Both infections were present in three herds $(6 \%)$. BNoV-infected calves were younger (median age 7 days) than nebovirus-infected calves (median age 21 days). These infections were not detected in adult cows and young stock over 6 months of age tested in selected herds. Risk factors identified for BNoV infection were a high number of preweaned calves present at the time of sampling, colostrum uptake by suckling the dam only, calf kept in a single pen, and geographic location of herd, while no risk factors for nebovirus infection were identified in the multivariable analysis. Univariable analysis suggested risk factors for nebovirus infection to be geographic location and early separation from the dam.
\end{abstract}

Keywords: bovine norovirus; nebovirus; RT-PCR; dairy calves; diarrhea; risk factors

\section{Introduction}

Bovine norovirus (BNoV) and nebovirus are genetically distinct enteric caliciviruses [1] $\mathrm{BNoV}$ are closely related to human noroviruses which are considered the worldwide leading cause of non-bacterial gastroenteritis [2]. Experimental infections with nebovirus in gnotobiotic calves caused intestinal lesions and diarrhea $[1,3]$. Experimental infections with BNoV in gnotobiotic calves (strain CV186-OH/00/US) produced lethargy and mild to moderate diarrhea with minute intestinal lesions but with prolonged fecal shedding [4]. In contrast, infection with BNoV-type strain Jena virus in conventional calves resulted in severe watery diarrhea and villous atrophy [5]. Both BNoV and nebovirus are frequently detected in naturally occurring calf diarrhea cases and an association has been shown between calf diarrhea and these infections [6]. Most prevalence studies, however, are small or not designed to test such association. The prevalence of $\mathrm{BNoV}$ among calves with diarrhea in various countries and herd systems has been highly variable: $3.3 \%$ [7], 4\% [8], 7.5\% [9], 9\% [10], 17\% [11], 20\% [12], 34\% [13], 40\% [14], 45\% [6], and 49\% [15]. Age of the calves and number of samples varied substantially between studies. The prevalence of nebovirus in diarrheic calves has been similarly reported: 3\% [11], 7\% [12], 9\% [16], 15\% [14], 22\% [6,13], 25\% [8], and 42\% [17]. Generally, a high proportion of BNoV- and nebovirus-positive calves were co-infected with other enteritis agents when such infections were analyzed. Previous work on $\mathrm{BNoV}$ and nebovirus has been focused on molecular studies, but little information on management risk factors for infection is available. 
The objectives of this study were to determine the prevalence of BNoV and nebovirus in Swedish dairy calves and investigate the association with diarrhea and herd and management factors.

\section{Materials and Methods}

\subsection{Sampling and Data Collection}

Fifty Swedish dairy herds were sampled for another purpose [18] and the samples, collected in 2005-2007, were made available for this study. Briefly, dairy herds with $\geq 50$ milking cows/year were randomly selected in five regions of Sweden from a list of all eligible herds in these regions as previously described [18]. The regions (Skåne, Västergötland, Östergötland, Uppland and southern Norrland, Figure 1) contained low, medium, and high-cattle-density areas. Herds were randomly selected in proportion to the regional source population as previously described [18]. Herds were visited once and fecal samples were collected rectally. Herd size and no. of calves at sampling are shown in supplementary Table S2. Samples from 10 calves $\leq 60$ days old were available from most herds. However, due to funding limitations, five calves aged 2-30 days per herd were analyzed in this study, this age group being the most likely to shed virus based on previous studies $[6,19,20]$. If more than five samples from calves in this age interval were available, then samples were chosen to cover the age interval. If less than five samples from calves in this age interval were available, then older calves were included. In 23 herds, at least one calf older than 30 days was included. Out of the analyzed calves, $78 \%$ were $\leq 30$ days-old. Presence of runny (no shape) or watery feces was classified as diarrhea in sampled calves. Number of calves per pen was recorded for the sampled calves, and a questionnaire on calf management at the herd level was completed at the visit [18]. Fecal samples were diluted $1: 10$ in sterile $0.9 \%$ saline and stored at $-20^{\circ} \mathrm{C}$ until analyzed.

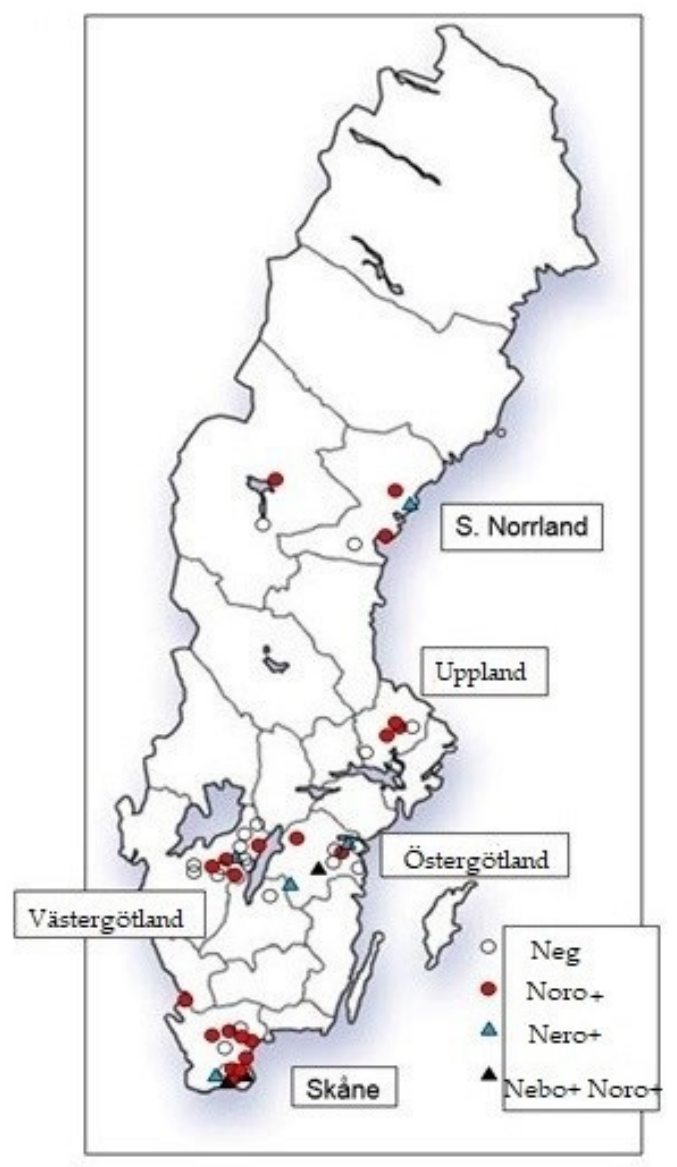

Figure 1. Geographic location of dairy herds positive or negative for bovine norovirus (Noro) and nebovirus (Nebo). 
Fecal samples from older cattle were analyzed in three herds where calves aged 230 days tested positive for $\mathrm{BNoV}$ and in three herds where such young calves tested positive for nebovirus. Samples analyzed in each of these herds included calves 31-60 days old $(n=3-5)$, heifers 5-9 months old $(n=4-5)$, and periparturient cows $(n=5)$. Herd size of these herds were $80-145$ cows (median 96 ).

\subsection{Detection of Bovine Norovirus and Nebovirus by RT-PCR}

Fecal samples were analyzed by one-step RT-PCR as previously described using primers J11U/CBECU-R for BNoV and NBU-F/NBU-R for nebovius detection [21]. Fecal samples were centrifuged at $1500 \times g$ for $10 \mathrm{~min}$. RNA was extracted from $280 \mu \mathrm{L}$ supernatant using QIAamp Viral RNA Mini kit (Qiagen, Hilden, Germany). AMV reverse transcriptase and GoTaq Flexi DNA polymerase were used in the RT-PCRs (Promega, Madison, WI, USA). To each reaction, $3 \mu \mathrm{L}$ of eluted RNA was added. Concentrations of reaction components and cycling conditions for the NBUF/R reaction were as previously described [21]. Cycling conditions for the BNoV were: RT $43{ }^{\circ} \mathrm{C} 60 \mathrm{~min}, 35$ cycles $94{ }^{\circ} \mathrm{C}$ $30 \mathrm{~s}, 56{ }^{\circ} \mathrm{C} 40 \mathrm{~s}, 72{ }^{\circ} \mathrm{C} 60 \mathrm{~s}$, and a final $10 \mathrm{~min}$ at $72{ }^{\circ} \mathrm{C}$. Positive and negative controls were included in every run. Amplification products were visualized by electrophoresis of $0.8 \%-2 \%$ agarose gels stained with GelRed (Biotium Inc., Fremont, CA, USA).

To confirm specificity of the RT-PCR reactions, one PCR product per positive herd was directly Sanger sequenced in both directions using a ABI 3730xl DNA Analyzer (Applied Biosystems, Foster City, CA, USA) conducted by Macrogen Europe Laboratory (Amsterdam, The Netherlands). Sequences were analyzed using Nucleotide BLAST at US National Center for Biotechnology Information (https:/ /blast.ncbi.nlm.nih.gov/, accessed on 13 November 2020) and BioEdit 7.2.5 [22].

\subsection{Statistical Analysis}

The associations between potential risk factors and presence of $\mathrm{BNoV}$, nebovirus, and signs of diarrhea were assessed with logistic regression analysis. We used a generalized estimation equation model, which accounts for the clustering of observations of calves within herd and provides parameter estimates that are consistent without having to specify the covariance structure.

Univariable associations for all potential risk factors were first screened, using Wilcoxon rank sum tests for continuous variables and Fisher's exact tests for categorical variables, and factors with a $p$-value $<0.2$ were retained for multivariable analyses. Multicollinearity among the risk factors were assessed by variance inflation factors (VIF), with a VIF $>10$ indicating too-severe multicollinearity. When this was the case, the factor with the strongest univariable association with the outcome was retained. The final multivariable models were built in a backward elimination process, where the variable with the highest $p$-value was eliminated until all remaining variables had a $p$-value $<0.05$. Confounding was investigated during the elimination process by assessing the relative change in estimates. A variable was considered as a confounder when its exclusion changed the coefficient of significant variables by $>25 \%$. Confounders were retained in the model regardless of their $p$-value. All statistical analyses were performed using $\mathrm{SAS}^{\circledR}$ version 9.4.

\section{Results}

\subsection{BNoV Prevalence and Association with Animal and Herd Factors}

Of the 250 young calves sampled, $50(20 \%)$ were positive for $\mathrm{BNoV}$ in 24 of the 50 herds sampled ( $48 \%$, Figure 1). In 17 herds, $\geq 2$ calves were BNoV-positive. Two of the BNoVpositive calves were older than 30 days. In the three herds where older cattle were tested, two heifers, 5 and 6-months-old, were positive for BNoV. No BNoV-positives were detected among adult cows and heifers over 6-months-old.

In the univariable analysis, $\mathrm{BNoV}$-positive calves were younger than negative ones (median 7 vs. 16 days, $p<0.001$, Table 1 ). Nine categorical and five continuous variables with $p<0.2$ in the univariable analysis (Table 1 ) were offered to the multivariable model. 
Four factors remained in the model (Table 2). There was a higher number of preweaned calves present in the herd at sampling of BNoV-positive than negative calves (median $20 \mathrm{vs}$. 14 , Table $1, \mathrm{OR}=3.9$ per 15 calves increase, Table 2). The prevalence of infection was lower when colostrum was routinely given by bottle than when the practices suckling only or suckling assisted by bottle feeding if needed (as determined by the care-taker) were used. Calves in single pens had a higher prevalence of infection than calves in group pens and there was a higher prevalence of $\mathrm{BNoV}$ infections in the region Skåne $(p<0.01)$ than in the other four regions.

Table 1. Factors univariably associated $(p<0.2)$ with bovine norovirus shedding detected by RT-PCR in 250 preweaned calves and offered to the multivariable regression model.

\begin{tabular}{|c|c|c|c|c|}
\hline Variable & Class & $\begin{array}{c}\text { No. of } \\
\text { Observations }\end{array}$ & $\begin{array}{l}\text { Percent } \\
\text { Positive }\end{array}$ & $p$-Value ${ }^{\mathrm{a}}$ \\
\hline \multirow{3}{*}{ Calves per pen } & 1 & 151 & 25 & \multirow{3}{*}{0.08} \\
\hline & $2-4$ & 58 & 16 & \\
\hline & $\geq 5$ & 41 & 10 & \\
\hline \multirow{5}{*}{ Region } & S. Norrland & 30 & 17 & \multirow{5}{*}{0.002} \\
\hline & Uppland & 25 & 32 & \\
\hline & Östergötland & 50 & 8 & \\
\hline & Västergötland & 70 & 13 & \\
\hline & Skăne & 75 & 32 & \\
\hline \multirow{3}{*}{ Colostrum feeding ${ }^{b}$} & Suckling only & 20 & 45 & \multirow{3}{*}{0.002} \\
\hline & Bottle if needed & 80 & 25 & \\
\hline & Bottle routinely & 150 & 14 & \\
\hline \multirow{3}{*}{ Age at diarrhea (weeks) ${ }^{c}$} & $<1$ & 65 & 25 & \multirow{3}{*}{0.11} \\
\hline & $1-3$ & 155 & 16 & \\
\hline & $>3$ & 30 & 30 & \\
\hline \multirow{2}{*}{ Housing } & Free stall & 140 & 29 & \multirow[b]{2}{*}{0.000} \\
\hline & Tie stall & 110 & 9 & \\
\hline \multirow{3}{*}{ Calving pen type ${ }^{\mathrm{d}}$} & Single & 150 & 23 & \multirow{3}{*}{0.02} \\
\hline & Multiple & 40 & 28 & \\
\hline & Not used & 60 & 8 & \\
\hline \multirow{2}{*}{$\begin{array}{l}\text { Time in calving pen before } \\
\text { calving (days) }\end{array}$} & $0-1$ & 95 & 29 & \multirow[b]{2}{*}{0.02} \\
\hline & $\begin{array}{l}2-5 \\
>5\end{array}$ & $\begin{array}{l}65 \\
35\end{array}$ & 12 & \\
\hline \multirow{3}{*}{ Single calf pens located } & Separate room & 15 & 0 & \multirow{3}{*}{0.03} \\
\hline & By group pens & 120 & 27 & \\
\hline & By young stock or cows & 85 & 19 & \\
\hline \multirow{3}{*}{ Cleaning of single calf pens } & Few times/year & 20 & 0 & \multirow{3}{*}{0.02} \\
\hline & Between calves & 100 & 27 & \\
\hline & Several times/calf & 100 & 21 & \\
\hline Continuous variable & $\begin{array}{l}\text { Median (IQ) }{ }^{\mathrm{e}} \text { norovirus } \\
\text { positive }(n=50)\end{array}$ & \multicolumn{2}{|c|}{$\begin{array}{l}\text { Median (IQ) }{ }^{\mathrm{e}} \text { norovirus } \\
\text { negative }(n=200)\end{array}$} & \\
\hline $\begin{array}{l}\text { No. of preweaned calves at } \\
\text { sampling }\end{array}$ & $20(12-30)$ & \multicolumn{2}{|c|}{$14(9-24)$} & 0.009 \\
\hline Calf density at sampling ${ }^{f}$ & $0.23(0.17-0.27)$ & \multicolumn{2}{|c|}{$0.20(0.12-0.25)$} & 0.06 \\
\hline Age of calves sampled & $7 \mathrm{~d}(5-12)$ & \multicolumn{2}{|c|}{$16 \mathrm{~d}(8-33)$} & 0.000 \\
\hline No. of cows/year & $78(63-110)$ & \multicolumn{2}{|c|}{$75(63-94)$} & 0.1 \\
\hline Milk yield $\mathrm{g}$ & $9300(8943-9840)$ & \multicolumn{2}{|c|}{$9550(8900-10,000)$} & 0.17 \\
\hline
\end{tabular}

a Wilcoxon rank sum test used for continuous variables, Fisher's exact test used for categorical variables; ${ }^{\mathrm{b}}$ Bottle if needed-the calf was assisted in ingesting its first meal by bottle-feeding or other types of assistance, as decided by the calf care-taker, Bottle routinely-first meal was offered by bottle to all calves; ${ }^{c}$ calf age when diarrhea is most commonly noticed in the herd; ${ }^{\mathrm{d}}$ Single-pen for one cow, Multiple-calving pen for a group of cows, Not used-herd does not have calving pens; ${ }^{\mathrm{e}}$ inter-quartile range; ${ }^{\mathrm{f}}$ no. of preweaned calves present at sampling/no. of cows/year; ${ }^{g}$ mean yield of ECM per cow during 12 months. 
Table 2. Multivariable regression model of factors associated with bovine norovirus shedding detected by RT-PCR in 250 preweaned calves.

\begin{tabular}{|c|c|c|c|c|}
\hline Variable & Class & $\begin{array}{l}\text { Parameter } \\
\text { Estimate }\end{array}$ & $\begin{array}{c}\text { Odds Ratio (95\% } \\
\text { Confidence Interval) }\end{array}$ & $p$-Value \\
\hline \multirow{3}{*}{ Calves per pen } & 1 & 1.61 & $5.0(1.6 ; 15.7)$ & \multirow{3}{*}{0.005} \\
\hline & $2-4$ & 0.40 & $1.5(0.4 ; 5.9)$ & \\
\hline & $\geq 5$ & $\operatorname{Ref}^{a}$ & 1 & \\
\hline \multirow{5}{*}{ Region } & S. Norrland & -0.89 & $0.4(0.1 ; 3.4)$ & \multirow{5}{*}{0.026} \\
\hline & Uppland & -0.33 & $0.7(0.2 ; 2.6)$ & \\
\hline & Östergötland & -1.42 & $0.2(0.1 ; 0.8)$ & \\
\hline & Västergötland & -1.81 & $0.2(0.1 ; 0.4)$ & \\
\hline & Skåne & ref & 1 & \\
\hline \multirow{3}{*}{ Colostrum feeding } & Suckling only & 2.64 & $14.1(3.2 ; 62.9)$ & \multirow{3}{*}{0.029} \\
\hline & Bottle if needed & 1.33 & $3.8(1.4 ; 10.0)$ & \\
\hline & Bottle routinely & ref & 1 & \\
\hline $\begin{array}{l}\text { No. of pre-weaned } \\
\text { calves at sampling }\end{array}$ & (continuous) & 0.07 & $3.9(1.6 ; 5.4)^{b}$ & 0.037 \\
\hline
\end{tabular}

Calf mortality within 60 days, among the 20 calves most recently born alive, was associated with detection of bovine norovirus shedding in the herd $(p=0.04$, Wilcoxon rank sum test). Calf mortality was not included in the multivariable model since the relationship was determined to be other than cause/risk factor (mortality) and effect (BNoV infection).

\subsection{Nebovirus Prevalence}

Thirteen young calves were positive for nebovirus (5.2\%). Eight herds (16\%) had 1-4 nebovirus-positive calves per herd (Figure 1). The prevalence was higher in Skåne and Östergötland than in the other regions in the univariable analysis $(p=0.04$, Table 3$)$. There was a tendency for a higher prevalence in calves that were separated from the cow within $24 \mathrm{~h}$ after birth compared with those separated later $(p=0.09)$. Nebovirus-positive calves tended to be older than negative ones (median 21 vs. 13 days). No statistically significant multivariable model could be built for nebovirus with the explanatory variables available.

Five calves in the age group 31-60 days were positive for nebovirus. In the three herds where older cattle were tested, none of the cows or heifers from 6 to 9-months old were nebovirus-positive.

Coinfection with $\mathrm{BNoV}$ and nebovirus was detected in one calf. Co-circulation of both viruses was detected in three herds (6\%, Figure 1$)$. In two of these herds, the farmer reported diarrhea commonly occurring in young calves, but no mortality.

Distribution of continuous variables in relation to $\mathrm{BNoV}$ or nebovirus infection or calf diarrhea and univariable analysis by Kruskall Wallis test is shown in Supplementary Table S1. 
Table 3. Factors univariably associated $(p<0.2)$ with nebovirus shedding detected by RT-PCR in 250 preweaned calves and offered to the multivariable regression model.

\begin{tabular}{|c|c|c|c|c|}
\hline Variable & Class & $\begin{array}{c}\text { No. of } \\
\text { Observations }\end{array}$ & $\begin{array}{l}\text { Percent } \\
\text { Positive }\end{array}$ & $p$-Value ${ }^{\text {a }}$ \\
\hline \multirow{5}{*}{ Region } & S. Norrland & 30 & 3 & \multirow{5}{*}{0.04} \\
\hline & Uppland & 25 & 0 & \\
\hline & Östergötland & 50 & 14 & \\
\hline & Västergötland & 70 & 1 & \\
\hline & Skåne & 75 & 5 & \\
\hline \multirow{3}{*}{ Colostrum feeding } & Suckling only & 20 & 5 & \multirow{3}{*}{0.11} \\
\hline & Bottle if needed & 80 & 1 & \\
\hline & Bottle routinely & 150 & 7 & \\
\hline \multirow{3}{*}{ Calving pen type } & Single & 150 & 5 & \multirow{3}{*}{0.10} \\
\hline & Multiple & 40 & 0 & \\
\hline & Not used & 60 & 10 & \\
\hline \multirow{3}{*}{$\begin{array}{l}\text { Time in calving pen } \\
\text { before calving (days) }\end{array}$} & $0-1$ & 95 & 6 & \multirow{3}{*}{0.18} \\
\hline & $2-5$ & 65 & 2 & \\
\hline & $>5$ & 35 & 0 & \\
\hline \multirow{2}{*}{ Cow and calf together } & $<24 \mathrm{~h}$ & 130 & 8 & \multirow{2}{*}{0.09} \\
\hline & $1-4 \mathrm{~d}$ & 120 & 2 & \\
\hline Continuous variable & $\begin{array}{c}\text { Median (IQ) } \\
\text { nebovirus positive } \\
\quad(n=13)\end{array}$ & \multicolumn{2}{|c|}{$\begin{array}{l}\text { Median (IQ) }{ }^{\mathrm{b}} \text { nebovirus } \\
\text { negative }(n=237)\end{array}$} & \\
\hline Age of calves sampled & $21 \mathrm{~d}(11-38)$ & \multicolumn{2}{|c|}{$13 \mathrm{~d}(6-27)$} & 0.12 \\
\hline No. of cows/year & 65 (48-99) & \multicolumn{2}{|c|}{75 (63-99) } & 0.19 \\
\hline
\end{tabular}

a Wilcoxon rank sum test used for continuous variables, Fischer's exact test used for categorical variables; $\mathrm{b}$ inter-quartile range.

\subsection{Calf Diarrhea}

Out of the 250 young calves sampled, $36(14.4 \%)$ had diarrhea at the time of sampling. Median age of calves with diarrhea was 11.5 days vs. 14.5 days for calves without diarrhea. Diarrhea at the time of sampling was not associated with detection of $\mathrm{BNoV}(17 \%$ vs. $21 \%$ of calves with vs. without diarrhea excreting BNoV, $p=0.59$, Chi2) or nebovirus ( $8 \%$ vs. $5 \%, p=0.36$, Chi2) in individual samples. Calf diarrhea perceived by the farmer as commonly occurring in the herd (12 herds) was not associated with detection of $\mathrm{BNoV}$ or nebovirus. Calf diarrhea was most common in the groups of 2-4 calves, in calves grouped at age 1-2 weeks, and when a higher no. of calves was present in the herd at sampling (Table 4 and 5). Calf diarrhea was also most common when practicing colostrum feeding by suckling the dam only. Calf diarrhea was less common when using single calving pens (Table 5). 
Table 4. Factors univariably associated $(p<0.2)$ with diarrhea (Yes/No) in 250 preweaned calves and offered to the multivariable regression model.

\begin{tabular}{|c|c|c|c|c|}
\hline Variable & No. of & Observations & $\begin{array}{l}\text { Percent } \\
\text { Positive }\end{array}$ & $p$-Value ${ }^{\mathrm{a}}$ \\
\hline \multirow{3}{*}{ Calves per pen } & 1 & 151 & 12 & \multirow{3}{*}{0.004} \\
\hline & $2-4$ & 58 & 28 & \\
\hline & $\geq 5$ & 41 & 5 & \\
\hline \multirow{3}{*}{ Calving pen type } & Individual & 150 & 11 & \multirow{3}{*}{0.08} \\
\hline & Group & 40 & 22 & \\
\hline & Not used & 60 & 18 & \\
\hline \multirow{3}{*}{ Colostrum Feeding ${ }^{b}$} & Suckling only & 20 & 25 & \multirow{3}{*}{0.19} \\
\hline & Bottle if needed & 80 & 10 & \\
\hline & Bottle routinely & 150 & 15 & \\
\hline \multirow{5}{*}{$\begin{array}{l}\text { Grouping calves at } \\
\text { age (weeks) }\end{array}$} & $<1$ & 35 & 6 & \multirow{5}{*}{0.14} \\
\hline & $1-2$ & 75 & 20 & \\
\hline & $2-3$ & 25 & 24 & \\
\hline & $3-4$ & 0 & & \\
\hline & $>4$ & 55 & 13 & \\
\hline Continuous variable & \multicolumn{3}{|c|}{$\begin{array}{l}\text { Median (IQ) }{ }^{\mathrm{c}} \text { no diarrhea } \\
\text { at sampling }(n=214)\end{array}$} & \\
\hline Calf density ${ }^{\mathrm{d}}$ & $0.24(0.17-0.27)$ & \multicolumn{2}{|c|}{$0.20(0.12-0.25)$} & 0.03 \\
\hline $\begin{array}{l}\text { No. of calves at } \\
\text { sampling }\end{array}$ & $22(12-28)$ & \multicolumn{2}{|c|}{$14(9-24)$} & 0.05 \\
\hline
\end{tabular}

$\bar{a}$ Wilcoxon rank sum test used for continuous variables, Fisher's exact test used for categorical variables; ${ }^{\mathrm{b}}$ not significant $(0.05<p<0.10)$ in the multivariable model, but acting as confounder; ${ }^{\mathrm{c}}$ inter-quartile range; ${ }^{\mathrm{d}}$ no. of preweaned calves present at sampling/no. of cows/year.

Table 5. Multivariable regression model of factors associated with diarrhea (Yes/No) in 250 preweaned calves.

\begin{tabular}{|c|c|c|c|c|}
\hline Variable & Class & $\begin{array}{c}\text { Parameter } \\
\text { Estimate }\end{array}$ & $\begin{array}{c}\text { Odds Ratio (95\% } \\
\text { Confidence Interval) }\end{array}$ & $p$-Value \\
\hline \multirow{3}{*}{ Calves per pen } & 1 & 0.66 & $1.9(0.5 ; 7.3)$ & \multirow{3}{*}{0.005} \\
\hline & $2-4$ & 1.90 & $6.7(1.7 ; 26.6)$ & \\
\hline & $\geq 5$ & ref $^{a}$ & 1 & \\
\hline \multirow{3}{*}{ Calving pen type } & Individual & -2.08 & $0.1(0.1 ; 0.3)$ & \multirow{3}{*}{0.021} \\
\hline & Group & -1.35 & $0.3(0.1 ; 0.6)$ & \\
\hline & Not used & ref & 1 & \\
\hline \multirow{3}{*}{$\begin{array}{l}\text { Colostrum } \\
\text { Feeding }\end{array}$} & Suckling only & 1.30 & $3.7(1.9 ; 7.1)$ & \multirow{3}{*}{0.079} \\
\hline & Bottle if needed & 0.31 & $1.4(0.6 ; 3.3)$ & \\
\hline & Bottle routinely & ref & 1 & \\
\hline \multirow{5}{*}{$\begin{array}{l}\text { Grouping calves at } \\
\text { age (weeks) }\end{array}$} & $<1$ & -1.26 & $0.3(0.1 ; 0.7)$ & \multirow{5}{*}{0.021} \\
\hline & $1-2$ & 0.77 & $2.2(1.1 ; 4.2)$ & \\
\hline & $2-3$ & 0.25 & $1.3(0.7 ; 2.5)$ & \\
\hline & $3-4$ & & & \\
\hline & $>4$ & ref & 1 & \\
\hline Calf density $b$ & (continuous) & -3.59 & $0.7(0.6 ; 0.9)^{\mathrm{c}}$ & 0.086 \\
\hline $\begin{array}{l}\text { No. of calves at } \\
\text { sampling }\end{array}$ & (continuous) & 0.03 & $1.6(1.1 ; 2.4)^{\mathrm{d}}$ & 0.041 \\
\hline
\end{tabular}

${ }^{\mathrm{a}}$ reference level; ${ }^{\mathrm{b}}$ not significant $(0.05<p<0.10)$ in the multivariable model, but acting as confounder; ${ }^{\mathrm{c}}$ calculated for an increase of 0.1 calves per cow (inter-quartile range); ${ }^{\mathrm{d}}$ calculated for an increase of 15 calves (inter-quartile range). 


\section{Discussion}

A herd level prevalence of $48 \%$ for $\mathrm{BNoV}$ and $16 \%$ for nebovirus indicates that these infections are common in Swedish dairy calves. A very similar herd level prevalence of $\mathrm{BNoV}, 50 \%$, was reported in a Norwegian study [15]. In other studies, proportion of infected herds is usually not reported, or not comparable due to sampling strategy. Individual calf prevalence, however, was similar to levels in other studies [6,11-14], considering that only $14 \%$ of the calves in our study had diarrhea at the time of sampling. A higher prevalence of $\mathrm{BNoV}$ than nebovirus in this study is consistent with the results of the majority of previous studies. The herds were randomly and proportionally selected based on national cattle statistics to ensure representative results. Still, the herd level prevalence is likely underestimated by this type of study, as herds are visited and sampled only once. No association between $\mathrm{BNoV}$ or nebovirus infection and diarrhea was detected, probably due to a low power because of the low number of diarrheic calves. Additionally, single sampling is not ideal for detecting such an association, depending on the availability of young calves at the time of sampling and considering that experimental studies suggest that the diarrhea period is shorter than the viral shedding period $[4,15]$. Considering the results from experimental studies, it is likely that these infections contribute to neonatal enteritis in infected cattle herds $[1,3,5]$. As we did not analyze other infections, it is difficult to pinpoint the effect of $\mathrm{BNoV}$ and nebovirus infections on calf health.

Herd sensitivity to detect a least one positive when sampling five calves $<30$ days of age is $92 \%$, assuming a $40 \%$ within-herd prevalence and a perfect test [23]. A high within-herd prevalence in this age group is likely, considering the extended shedding of $\mathrm{BNoV}$ previously reported $[4,24]$, and the $\mathrm{BNoV}$ positive herds in this study had a mean of two positive calves (40\%). Assuming that the specificity of the RT-PCR is $99 \%$, sampling five calves leads to a herd specificity of $95 \%$, while a test specificity of $98 \%$ leads to a herd specificity of $90 \%$ [23]. Since there are no previous estimates of $\mathrm{BNoV}$ and nebovirus within-herd prevalence in Swedish dairy calves, we cannot preclude the possibility that sampling only five calves per herd underestimates the prevalence. There is also a possibility that the prevalence of these viruses may differ today, since the samples we had access to for this study were collected $>10$ years ago. BNoV being detected mainly in very young calves (median age 7 days) in this study is consistent with results from other studies where the age of infected calves is reported $[6,19,20]$. One study, however, detected peak number of shedding calves at age 2.5 months [24]. That study also reported a low number of adult cows shedding BNoV, which was not found here. The nebovirus-positive calves in our study were older than the BNoV-positive calves (median age 21 days vs. 7 days). This finding may suggest that nebovirus can cause diarrhea in older calves in addition to the neonatal ones, or that shedding of nebovirus tends to be more extended. Samples from older calves, young stock, and cows were, due to funding limitations, analyzed in only a small number of herds. Shedding may not have been picked up by the sampling strategy if the within-herd prevalence in these age groups was low. However, we increased the herd sensitivity by selecting herds for testing where young calves were shedding the virus. The results suggested that the prevalence in these age groups is lower than in the young calves.

A higher number of calves in the herd is a reasonable risk factor for $\mathrm{BNoV}$ infection, since transmission of infections most likely is enhanced when a larger pool of susceptible young calves are present. Calf density, as a measure of a higher than average concentration of neonatal calves at the time of sampling, is often reported from field veterinarians as associated with neonatal enteritis outbreaks. In the multivariable models, this factor was not associated with the infections investigated in this study. The finding is not surprising, however, since the investigated herds were not selected based on history of any calf diarrhea problems. Relying on spontaneous suckling for colostrum intake has been shown in several studies to reduce calf levels of maternal antibodies [25]. This was also a risk factor for $\mathrm{BNoV}$ in our study and indicated, as expected, that maternal antibodies most likely are important to protect the calf from these infections, underlining the importance of manual colostrum routines for calf health. 
A surprising finding was the higher $\mathrm{BNoV}$ prevalence in single pens than in group pens, as the infectious pressure generally would be assumed to be higher in groups. Possible explanations may be that the youngest calves, that are the most sensitive to BNoV infection as shown in this study, are kept in single pens more often than older calves, even though age was not identified as a significant factor in the multivariable model in this study. The older calves in group pens would thus already be immune to the virus. Herd location in the southern region Skåne was identified as a risk factor for infection. A possible explanation for this might be that Skåne is a high-density cattle area with potentially more direct and indirect inter-herd contacts transmitting infections [26].

No multivariable model could be built for nebovirus infection, most likely because of the low number of positive calves. In the univariable analysis, herd location in regions Skåne and Östergötland was identified as risk factors. The region Östergötland is also partly cattle-dense, so this finding is not surprising. Early separation of calf from cow tended to be associated with a higher nebovirus prevalence. This finding is interesting since early separation is often recommended to ensure proper feeding of the first colostrum and to reduce transmission of pathogens from the dam [27]. A longer period of access to colostrum and transition milk by spontaneous suckling may afford local protection in the gut against infection [28], partly explaining this finding.

The risk factors for calf diarrhea identified in this study are in agreement with previous studies: a higher prevalence in small groups where calves are likely to be younger, in calves grouped very early at 1-2 weeks old, when a larger number of preweaned calves were present and when colostrum was fed by suckling only $[25,29,30]$. In contrast to the results for $\mathrm{BNoV}$ infection, there was a tendency for calf density being a risk factor for calf diarrhea at sampling in the multivariable model. This finding was expected since diarrhea at sampling may have been caused by an array of unidentified agents. Single-cow calving pen was identified as a protective factor, which was expected, since single pens generally offer a more hygienic environment for the newborn calf and also less risk of colostrum intake failure. Further research is needed to assess the overall effects of $\mathrm{BNoV}$ and nebovirus on calf health.

\section{Conclusions}

Bovine norovirus and nebovirus are common infections in young Swedish dairy calves. $\mathrm{BNoV}$ was detected more frequently and $\mathrm{BNoV}$-infected calves were younger than nebovirus-infected. Risk factors identified for $\mathrm{BNoV}$ infection were a high number of preweaned calves present, colostrum intake by suckling only, calf kept in a single pen, and geographic location of herd, while no risk factors for nebovirus infection were identified in the multivariable analysis.

Supplementary Materials: The following are available online at https://www.mdpi.com/article/10 .3390/dairy3010011/s1, Table S1: Distribution of continuous variables and univariable analysis by Kruskall Wallis test, Table S2: Herd size, no. of milkfed calves present at sampling, no. of samples from calves available from the previous study and no. of samples analyzed in this study.

Author Contributions: Conceptualization, M.T. and U.E.; data curation, M.T., C.A. and U.E.; formal analysis, A.S. and U.E.; funding acquisition, M.T.; investigation, C.A. and C.B.; methodology, M.T., A.S. and U.E.; visualization, M.T.; writing — original draft, M.T.; writing—review and editing, all authors. All authors have read and agreed to the published version of the manuscript.

Funding: This research was funded by the Swedish Farmers' Foundation for Agricultural Research, grant number V0830393.

Institutional Review Board Statement: Not applicable.

Informed Consent Statement: Not applicable.

Data Availability Statement: The dataset generated and analyzed during this study is openly available at the Swedish University of Agricultural Sciences depository DSpace (https: / /archiveharvest.slu.se:8443/jspui/handle/20.500.12703/3937, accessed on 1 September 2021). 
Conflicts of Interest: The authors declare no conflict of interest. The funders had no role in the design of the study; in the collection, analyses, or interpretation of data; in the writing of the manuscript, or in the decision to publish the results.

\section{References}

1. Smiley, J.R.; Chang, K.O.; Hayes, J.; Vinjé, J.; Saif, L.J. Characterization of an enteropathogenic bovine calicivirus representing a potentially new calicivirus genus. J. Virol. 2002, 76, 10089-10098. [CrossRef] [PubMed]

2. Oliver, S.L.; Dastjerdi, A.M.; Wong, S.; El-Attar, L.; Gallimore, C.; Brown, D.W.G.; Green, J.; Bridger, J. Molecular characterization of bovine enteric caliciviruses: A distinct third genogroup of noroviruses (Norwalk-like viruses) unlikely to be of risk to humans. J. Virol. 2003, 77, 2789-2798. [CrossRef] [PubMed]

3. Bridger, J.C.; Hall, G.A.; Brown, J.F. Characterization of a calici-like virus (Newbury agent) found in association with astrovirus and bovine diarrhea. Infect. Immun. 1984, 43, 133-138. [CrossRef]

4. Jung, K.; Scheuer, K.A.; Zhang, Z.; Wang, Q.; Saif, L.J. Pathogenesis of GIII.2 bovine norovirus, CV186-OH/00/US strain in gnotobiotic calves. Vet. Microbiol. 2014, 168, 202-207. [CrossRef] [PubMed]

5. Otto, P.H.; Clarke, I.N.; Lambden, P.R.; Salim, O.; Reetz, J.; Liebler-Tenorio, E.M. Infection of calves with bovine norovirus GIII.1 strain Jena virus: An experimental model to study the pathogenesis of norovirus infection. J. Virol. 2011, 85, 12013-12021. [CrossRef]

6. Cho, Y.I.; Han, J.I.; Wang, C.; Cooper, V.; Schwartz, K.; Engelken, T.; Yoon, K.J. Case-control study of microbiological etiology associated with calf diarrhea. Vet. Microbiol. 2013, 166, 375-385. [CrossRef] [PubMed]

7. Ferragut, F.; Vega, C.G.; Mauroy, A.; Conceicao-Neto, N.; Zeller, M.; Heylen, E.; Uriarte, E.L.; Bilbao, G.; Bok, M.; Matthijnssens, J.; et al. Molecular detaction of bovine norovirus in Argentinean dairy calves; circulation of a tentative new genotype. Infect. Genet. Evol. 2016, 40, 144-150. [CrossRef] [PubMed]

8. Turan, T.; Isidan, H.; Atasoy, M.O.; Irehan, B. Detection and molecular analysis of bovine enteric norovirus and nebovirus in Turkey. J. Vet. Res. 2018, 62, 129-135. [CrossRef] [PubMed]

9. Mauroy, A.; Scipioni, A.; Mathijs, E.; Saegerman, C.; Mast, J.; Bridger, J.C.; Ziant, D.; Thys, C.; Thiry, E. Epidemiological study of bovine norovirus infection by RT-PCR and VLP-based antibody ELISA. Vet. Microbiol. 2009, 137, 243-251. [CrossRef]

10. Park, S.I.; Jeong, C.; Kim, H.H.; Park, S.H.; Park, S.J.; Hyun, B.H.; Yang, D.K.; Kim, S.K.; Kang, M.I.; Cho, K.O. Molecular epidemiology of bovine noroviruses in South Korea. Vet. Microbiol. 2007, 124, 125-133. [CrossRef] [PubMed]

11. Hassine-Zaafrane, M.; Kaplon, J.; Sdiri-Loulizi, K.; Aouni, Z.; Pothier, P.; Aouni, M.; Ambert-Balay, K. Molecular prevalence of bovine noroviruses and neboviruses detected in central-eastern Tunisia. Arch. Virol. 2012, 157, 1599-1604. [CrossRef] [PubMed]

12. Kaplon, J.; Guenau, E.; Asdrubal, P.; Pothier, P.; Ambert-Balay, K. Possible novel nebovirus genotype in cattle, France. Emerg. Infect. Dis. 2011, 17, 1120-1123. [CrossRef] [PubMed]

13. Karayel-Hacioglu, I.; Alkan, F. Molecular characterization of bovine noroviruses and neboviruses in Turkey; detection of recombinant strains. Arch. Virol. 2019, 164, 1411-1417. [CrossRef] [PubMed]

14. Pourasgari, F.; Kaplon, J.; Sanchooli, A.; Fremy, C.; Karimi-Naghlani, S.; Otarod, V.; Ambert-Balay, K.; Mojgani, N.; Pothier, P. Molecular prevalence of bovine noroviruses and neboviruses in newborn calves in Iran. Arch. Virol. 2018, 163, $1271-1277$. [CrossRef]

15. Jor, E.; Myrmel, M.; Jonassen, C.M. SYBR Green based real-time RT-PCR assay for detection and genotype prediction of bovine norovirus and assessment of clinical significance in Norway. J. Virol. Methods 2010, 169, 1-7. [CrossRef]

16. Park, S.I.; Jeong, C.; Park, S.J.; Kim, H.H.; Jeong, Y.J.; Hyun, B.H.; Chun, Y.H.; Kang, M.I.; Cho, K.O. Molecular detection and characterization of unclassified bovine enteric caliciviruses in South Korea. Vet. Microbiol. 2008, 130, 371-379. [CrossRef]

17. Guo, Z.; He, Q.; Zhang, B.; Yue, H.; Tang, C. Detection and molecular characteristics of neboviruses in dairy cows in China. J. Genet Virol. 2019, 100, 35-45. [CrossRef]

18. Silverlås, C.; Emanuelson, U.; de Verdier, K.; Björkman, C. Prevalence and associated management factors of Cryptosporidium shedding in 50 Swedish dairy herds. Prev. Vet. Med. 2009, 90, 242-253. [CrossRef]

19. Wise, A.G.; Monroe, S.S.; Hanson, L.E.; Grooms, D.L.; Sockett, D.; Maes, R.K. Molecular characterization of norovirus detected in diarrheic stools of Michigan and Wisconsin dairy calves: Circulation of two distinct subgroups. Virus Res. 2004, 100, 165-177. [CrossRef]

20. Milnes, A.S.; Binns, S.H.; Oliver, S.L.; Bridger, J.C. Retrospective study of norovirus in samples of diarrhea from cattle, using the Veterinary Laboratories Agency's Farmfile records. Vet. Rec. 2007, 160, 326-330. [CrossRef]

21. Smiley, J.R.; Hoet, A.E. Tråvén, M.; Tsunemitsu, H.; Saif, L.J. Reverse transcription-PCR assays for detection of bovine enteric caliciviruses (BEC) and analysis of the genetic relationships among BEC and human caliciviruses. J. Clin. Microbiol. 2003, 41, 3089-3099. [CrossRef] [PubMed]

22. Hall, T.A. BioEdit: A user-friendly biological sequence alignment editor and analysis program for Windows 95/98/NT. Nucl. Acids Symp. 1999, 41, 95-98.

23. Dohoo, I.; Martin, W.; Stryhn, H. Veterinary Epidemiologic Research, 2nd ed.; VER Inc.: Charlottetown, PEI, Canada, 2010; pp. 122-126.

24. Van der Poel, W.H.M.; van der Heide, R.; Verschoor, F.; Gelderblom, H.; Vinjé, J.; Koopmans, M.P.G. Epidemiology of Norwalk-like virus infections in cattle in the Netherlands. Vet. Microbiol. 2003, 92, 297-309. [CrossRef] 
25. Godden, S. Colostrum management for dairy calves. Vet. Clin. Food Anim. 2008, 24, 19-39. [CrossRef]

26. Ohlson, A.; Alenius, S.; Tråvén, M.; Emanuelson, U. A longitudinal study of the dynamics of bovine coronavirus and respiratory syncytial virus infections in dairy herds. Vet. J. 2013, 197, 395-400. [CrossRef]

27. McGuirk, S.M.; Collins, M. Managing the production, storage and delivery of colostrum. Vet. Clin. Food Anim. 2004, 20, 593-603. [CrossRef]

28. Berge, A.C.B.; Besser, T.E.; Moore, D.A.; Sischo, W.M. Evaluation of the effects of oral colostrum supplementation during the first fourteen days on the health and performance of preweaned calves. J. Dairy Sci. 2009, 92, 286-295. [CrossRef]

29. Weaver, D.M.; Tyler, J.W.; VanMetre, D.C.; Hostetler, D.E.; Barrington, G.M. Passive transfer of colostral immunoglobulins in calves. J. Vet. Intern. Med. 2000, 14, 569-577. [CrossRef]

30. Gulliksen, S.M.; Jor, E.; Lie, K.I.; Hamnes, I.S.; Løken, T.; Åkerstedt, J.; Østerås, O. Enteropathogens and risk factors for diarrhea in Norwegian dairy calves. J. Dairy Sci. 2009, 92, 5057-5066. [CrossRef] 